The early insurance companies charged a flat rate of $5 l$. per cent. for members of all ages, which was unfair to their younger members, but profitable to the companies. Then Price was lucky enough to come across the work of that worthy clerk of Northampton whose bills of mortality were prefaced each year by verses of the poet Cowper, and by the aid of those bills constructed a table of mortality. His method was erroneous, but the error was on the right side, for he made the mortality to be greater than it really was, and so as long as the Northampton table was used the prosperity of the companies continued. Then Milne constructed another table from the mortality experienced at Carlisle. Milne's methods were correct, but his table, being based on a limited local experience, was founded on insufficient data and was unevenly graduated. Still it served as a standard table for very many years, until Farr prepared from the Registrar-General's returns for the whole population the English life tables. These failed in the other direction; they were too general. We are not including in these observations the industrial insurances.

In these circumstances the Institute of Actuaries constructed a table from the actual experience of the companies, known as the $\mathrm{H}^{\mathrm{m}}$ or healthy male table; but by the year 1893, as Mr. George King wrote, "it came to be felt that the Institute of Actuaries' experience was passing out of date." It was resolved to construct a table of mortality on the experience of sixty companies during the thirty years from 1863 to 1893 , leaving out of account all the experience of the earlier days of the companies. In Igor (not "a half-century ago," as Dr. Campbell puts it) tables based on this experience were published, and they are now the standard tables in use.

It appears from all we have said that the insurance companies have been alive to the fact that the duration of life has been gradually increasing, and have not been unwilling to give their policyholders from time to time the benefit of the advance of knowledge in that respect. The war has now come to throw a new and lurid light on this question. It has destroyed the lives or ruined the health of many of those "whose lives have been accepted as risks to be insured." But it will come to an end some day, and normal conditions will in time be restored. Meanwhile, we may be well content with the materials with which actuarial science has already furnished us.

\section{TROPICAL DISEASES.}

THE Bulletin of the St. Louis University for January, I916, contains a report of the work of the expedition sent by the University to British Honduras last summer for the study of tropical diseases. This expedition, intentionally planned for the purpose of a preliminary study of methods of procedure, etc., illustrates the advantage of these research expeditions. It is not that laboratories do not exist and that research is not carried out in British Honduras, but such an expedition comes with a fresh outlook on problems, and matters which may be taken to be among the most ordinary events, scarcely worthy of record in official reports, strike the members of an expedition with an entirely fresh force. We may illustrate this by two interesting examples, though perhaps not of great importance. We do not recollect in the official reports of British Honduras-and, indeed, it may be because one does not read official reports sufficiently carefully-the occurrence of poisoning, said to be common during the summer months, by the baracouta fish, nor do we recollect having heard of this on the West Coast of Africa, where the baracouta forms a welcome addition to the ordinary diet of skinny chickens. Again, the "botlass" fly (unidentified), after alighting on the skin, leaves a black, hard spot and the bite is very painful. This, again, to us is a new fact and one certainly that should be investigated.

The Bulletin has a special interest in that it contains an "In Memoriam" notice of the life and work of Dr. Edward Nelson Tobey, who was in charge of this expedition to British Honduras to study tropical diseases. He lost his life on the ship Marowijne, in a West Indian hurricane, on August 14 . His life, as recorded here, was "one of unreached ambition and of unrealised hope. It was all effort and venture, with but little fruition and rest." The words of Meredith's sonnet on "Internal Harmony"-

So that I draw the breath of finer air

Station is nought, nor footways laurel-strewn

Nor rivals tightly belted for the race.

Good speed to them! My place is here or there;

My pride is that among them I have place:

And thus I keep this instrument in tune-

are, as those who knew "old Tobey" personally can confidently assert, well applicable to him.

J. W. W. S.

\section{THE MITTAG-LEFFLER INSTITUTE.}

T $T$ was announced in our issue of March 23 (p. 85) that Mme. Mittag-Leffler and her husband, Prof. G. Mittag-Leffler, the eminent mathematician, had made a will devoting the whole of their property to the promotion of pure mathematics. Details of this significant foundation are given in the Revue générale des Sciences of May 30, from which the following particulars have been derived :-

The bequest includes their freehold villa with its contents, among which is a fine mathematical library; and an endowment to provide for its upkeep, salary of its curator, and other specified purposes. To encourage the study of pure mathematics in Sweden, Denmark, Finland, and Norway there are to be bursaries tenable by young people of both sexes belonging to these countries; they must show real aptitude for research in pure mathematics, but may pursue their studies at home or abroad. There is to be a gold medal, similar to the minor Nobel medal, for pure mathematicians belonging to the aforesaid countries who produce works above the average; and a prize for pure mathematics, to be awarded, if possible,

No. 2436 , VOL. 97 ] 
at least once in every six years, which is open to the whole world. The only express condition is that the award is to be for discoveries of real importance in the domain of pure mathematics.

It is intended that the director of the institute should be an eminent, and at the same time sympathetic, mathematician. The library will be available for all serious students, and they will have the privilege of consulting the director. Part of his duties will consist in giving courses of lectures to a limited number of "really gifted auditors, keenly interested in his discourses." Prof. Mittag-Leffler states that, in making his arrangements, he has taken as his model the Pasteur Institute; and the final clause of this enlightened and far-seeing document is as follows :-

Our will owes its origin to the lively conviction that a people which does not hold Mathematics in high esteem will never be able to fulfil the loftiest duties of civilisation; and that consequently it will fail to enjoy that international consideration which, in the long run, farms an effective means of preserving our status in the world, and of maintaining our right to live our individual life. ${ }^{1}$

We have only to add that in our opinion this is a noble example of well-directed patriotism and philanthropy which ought to lead to many imitations.

\section{NOTES}

WE learn with much regret that Prince Boris Galitzin, professor of physics in the Imperial Academy of Sciences, Petrograd, and a distinguished worker in seismology, died on April 21/May 4.

WE notice with deep regret the announcement of the death on June 30 , at seventy years of age, of Sir Gaston Maspero, the well-known Egyptologist and permanent secretary of the Académie des Inscriptions et Belles-Lettres, Paris.

THE twenty-seventh annual meeting of the Museums Association will be held at Ipswich $n$ Tuesday and Wednesday, July II and I2, under the presidency of Mr. E. Rimbault Dibdin, Curator of the Walker Art Gallery, Liverpool.

THE annual general meeting of the Eugenics Education Society will be held at the Grafton Galleries, London, W., to-day (July 6), at 4 p.m., when the presidential address will be delivered by Mr. Leonard Darwin.

A special Prize Fellowship of rool., offered by the Federation of University Women to encourage research on some questions of special interest in the present national crisis, has been awarded by the Federation to Dr. Alice Lee, Fellow of University College, London. Miss Lee has collaborated for some years with Dr. Karl Pearson in many statistical irvestigations, and is also the author of several independent communications. She is about to undertake an investigation into the birth-rate as affected by present conditions.

IN the Times of July 3 its special correspondent, in describing the battle on the Somme, refers to the

1 " Notre testament doit son origine à la vivante conviction qu'un peuple qui n'accorde pas aux Mathematiques un rang élevé dans son estime, ne sera jamais en état de remplir les plus hautes tâches civilisatrices et de jouir, par suite, de la considération internationale qui, elle aussi, constitue a la longue un moyen efficace de conserver notre situation dans le monde et dongue garder notre droit à vivre notre propre vie."

NO. 2436 , VOL. 97$]$ occasional inaudibility of the gun-firing at short distances. "Last night" (June 29), he says, "I watched the bombardment from a position commanding a view of a large section of the front. . . . It was a soft dark night, with a light westerly wind. ... The comparative noiselessness of the bombardment from near at hand last night was very curious.' On the hilltop where he stood he was unable to hear " any sound save of the guns immediately by us, with occasional bursts of sound coming quite illogically from far away. And all the while the flare and flashing of the shells was continuous."

We regret to announce that $M$. Emile Waxweiler, who before the war was the director of the Solvay Institute of Sociology at Brussels University, was killed in Londion on June 26 by a motor-car. An appreciative account of M. Waxweiler's work, in the Times of June 29 , points out that the sociological studies prodused by him and under his direction were models of scientific inquiry. Among his best-known works before the war are his "High Wages in the United States" and "Profit Sharing." He was recently appointed director of the Belgian Office of Economic Studies, established in London to ascertain the needs of Belgian trade and industry; and he was also chosen as a delegate to the recent Economic Conference at Paris, where he was the right hand of the Belgian Premier, M. de Broqueville.

A Deputation from the Royal Scottish Arboricultural Society met a number of Scottish members at the House of Commons on July 4 and laid before them the case for the creation of a Department of Forestry connected with the Board of Agriculture, for the development of forestry in Scotland, and the preparation of schemes of afforestation. In connection with this subject the Parliamentary correspondent of the Times states that the Government has decided to conduct an inquiry into the subject of afforestation after the war. The inquiry has been entrusted to a sub-committee of the Reconstruction Committee of the Cabinet.

THE failure of the Uruguayan trawler Instituto Pesca to reach Sir Ernest Shackleton's men on Elephant Island was not surprising in view of the fact that she is an unprotected vessel and made the attempt in the Antarctic midwinter. The Uruguayan Government, however, has ordered her to lie at Punta Arenas awaiting a more favourable opportunity. Meanwhile the damage she sustained in the ice is being repaired. Open water up to Elephant Island is quite possible in any month of the year, but it can never be relied on, and so the chances of the Instituto Pesca succeeding are most problematical. The Argentine sloop Uruguay, which rescued the wrecked Swedish expedition in 1903, is unfit for service. But it is reported that the Chilian Government has a wooden whaler, which has been offered to Sir Ernest Shackleton. If she is in good repair, this vessel should be able to reach the marooned men, for even if heavv pack is encountered a strong wooden ship could either force a passage or lie and wait for the pack to slacken. This appoars to be the only possible ship in South American waters. A suitable ship could be secured in this country, but, at the earliest, could not reach Elephant Island before the end of August. If, however, Sir Ernest Shackleton reports that the shipping resources of South America cannot meet the demand, a vessel will be sent from home.

ThE Manchester City Council (governing body of the Manchester School of Technology) has just decided to establish forthwith a new sub-department of the school for post-graduate study and research in coal- 